\title{
Some Dictionary Descriptions of Grammatical Structure
}

\author{
William Branford, Department of Linguistics, University of Cape Town
}

Opsomming: Enkele woordeboekbeskrywings van grammatikale struktuur. Hierdie artikel ondersoek enkele aspekte van die behandeling van grammatikale struktuur in vier resente woordeboeke wat Engels as eerste taal aanbied. Dié aspekte word teen die agtergrond van die konsepte "leksikogrammatika" (Halliday 1978) en die interafhanklikheid van leksikografiese en sintaktiese taalbeskrywing beskou. Die artikel is noodwendig verkennend van aard. Die eerste van die hoofafdelings is teoreties; die tweede ondersoek enkele kontemporêre hanteringswyses van sin, klous en stuk; die derde bied uitgesoekte ooorbeelde aan en vestig die aandag op die hanteringswyses van determinante, intensifiseerders en komplementeringspatrone, terwyl dit ook kyk na die korrelasie tussen woordeboeketikette en struktuurbeskrywings aan die een kant en die werklike taalsisteem aan die ander kant. Enkele noodwendig voorlopige gevolgtrekkings word gemaak.

Sleutelwoorde: LEKSIKOGRAMMATIKA, LEKSIKOGRAFIESE TAALBESKRYWING, SINTAKTIESE TAALBESKRYWING

\begin{abstract}
This paper examines some points in the treatment of grammatical structure in four recent dictionaries of English as L1. These are viewed against the background concepts of "lexicogrammar" (Halliday 1978) and of the interdependence of lexicographical and syntactic descriptions of language. Its scope is necessarily exploratory. The first of its three main sections is theoretical; the second examines some contemporary dictionary treatments of sentence, clause, and phrase; the third presents selected specifica, focussing on treatments of determiners, intensifiers and patterns of complementation, and on the "goodness of fit" between dictionary labellings and "structural descriptions" and the actual language system. Some necessarily tentative conclusions are drawn.
\end{abstract}

\section{Keywords: LEXICOGRAMMAR, LEXICOGRAPHICAL DESCRIPTION OF LANGUAGE,} SYNTACTIC DESCRIPTION OF LANGUAGE

\section{Lexicogrammar}

Dictionaries, one might argue, describe grammatical structure only incidentally: their main business is with word-meanings. And in linguistics, during this century, there has been a marked shift from Saussure's concept of langue as a "kind of thesaurus", imprinted on the brain of every speaker, to Chomsky's concept (1957) of a language as a set of (grammatically correct) sentences, or 
Hudson's more promising "a language is a network of entities related by propositions" (Hudson 1984: 1). But it is a mistake to divorce sign from system, or lexis from grammar: witness TGG and case-grammar studies of "lexical entries"; the title and argument of Hudson's Word Grammar, Matthews's concept of valency: "Valency is the term used in dependency theory to refer to the particular demands of individual words for modifiers" (Hudson 1984: 120); and Halliday's "lexicogrammar" constituting a single level for analysis (Halliday 1978). Good lexicographers, moreover, have had a concern for syntax ever since Johnson (1755) wrote in his Preface: "The various syntactical structures occurring in the examples have been carefully noted." The copious "examples" were a major strength of Johnson's Dictionary, making it, like Oxford English Dictionary, a mine of grammatical information, though in both texts much of this has to be gleaned from the illustrative quotations and is not spelled out explicitly.

A very explicit spelling-out is attempted in some dictionaries for the student of English as L2, e.g. the Longman Dictionary of Contemporary English, to be noticed briefly later.

Exemplification is one matter, terminology another. Dictionaries for the general reader can do no more than sample the enormous terminologies which various linguistic sects have built up from Bloomfield (1933) onwards. The specialized vocabularies of the sciences, and particularly the social sciences, lie at the fringe of the commercial lexicographer's field of interest. Gone are the days when Johnson could write:

Of the terms of art I have received such as could be found either in books of science or technical dictionaries.

The proliferation since Johnson's time of specialized vocabularies means that the ordinary desk dictionary can select from any field of specialization only a few terms likely to help or interest the general reader.

Linguistics, moreover, compared say with environmental studies, has for long suffered from an ivory-tower remoteness which it is only just beginning to lose with the impact of such blueprints for language education as the Kingman Report and of magazines such as English Today.

What dictionaries do say about grammatical structure, however, is of some social importance. In many English households "the dictionary" is likely to be the only book about the English language that is regularly consulted. School textbooks on English are (often deservedly) relegated to the garage or the jumble sale. "The dictionary" is thus a major source of what ordinary people "know" about English.

This is somewhat limiting in a century in which linguistic studies have done so much to improve the available descriptions of English - and of language generally - in scope, in coherence and in depth of insight. 


\section{Dictionaries Sampled}

The dictionaries sampled for this paper are listed below, each after the acronym which will be used to refer to it:

$\begin{array}{ll}\text { CCDP } & \text { Collins Concise English Dictionary Plus, } 1989 \text { (1975 } \\ & \text { pages); } \\ \text { COD } & \text { Concise Oxford Dictionary, } 1990 \text { (1494 pages); } \\ \text { CSD } & \text { Collins School Dictionary, 1989 (848 pages); } \\ \text { EUD } & \text { English Usage Dictionary for South African Schools, } \\ & \text { Third edition 1988 (1036 pages). }\end{array}$

CCDP and COD are recent "middleweight" general readers' dictionaries; CSD is a school dictionary primarily for L1 classes. EUD aims possibly both at L1 and L2 classes. It is a "double-entry" text, with each entry patterned like this:

$$
\begin{array}{ll}
\text { expend } & \text { they expend }[v](\text { eks-pend) too much } \\
\text { to use up } & \text { energy on jogging. }
\end{array}
$$

For each headword the left-hand column gives one or more brief definitions. The right-hand column gives examples of use, with an indicator of word-class, here [ $v$ ] and a simplified phonetic notation. It thus relies heavily on straightforward exemplification. Just for the record: both COD and CCDP use IPA notation; CSD has no pronunciation key.

Brief reference is also made to

LDOCE: $\quad$ Longman Dictionary of Contemporary English, 1978 (1303 pages)

in its time a pioneer new-style dictionary for the L.2 learner.

\section{How Dictionaries Reflect Grammatical Structure}

Grammatical categories and structures are typically reflected in dictionaries in four different ways:

(a) In sections of grammatical information in what, for brevity's sake, will here be called the Preliminaries (i.e. introductory pages);

(b) In entries for grammatical terms, e.g. sentence, in the main alphabetical series;

(c) Among the set of abbreviations (e.g. adj., adv., n. and v.) listed in the Preliminaries and used throughout the text; and

(d) In examples or illustrative quotations. 
Of these (c) and (d) are probably the most influential. Many readers will skip Preliminaries. Johnson (1755) includes a quite lengthy outline of English grammar in his Preliminaries; this focusses mainly on morphology and is best known for its dismissive comments on "Syntax":

"our language has so little inflection or variation of termination, that its construction neither requires nor admits many nules."

In more recent dictionaries for the $\mathrm{L} 1$ market, as we shall see, grammatical preliminaries tend to be pared to a minimum. CSD devotes six of its nine introductory pages to "Grammar: the Structure of Language". Most of the grammatical information in COD is built into the text. EUD has only a two-page "Guide to Users". CCDP has a six-page guide of which about one page deals with "Parts of Speech" and other grammatical information. LDOCE, by comparison, has $\mathbf{4 0}$ pages of Preliminaries explaining a complex grammatical notation used throughout the text.

An L1 dictionary's basic set of grammatical abbreviations will usually stick fairly closely to terms which the reader is likely to think s/he understands. There is a risk in the use of "unfamiliar jargon". To most readers, probably, examples of use (as in EUD) are likely to be the most trouble-free grammatical aids.

\section{Sentence, Clause and Phrase}

The effectiveness of a terminology often depends on its capturing the interconnectedness of its members, e.g. the interdependence in grammatical analysis of the cluster of terms which includes sentence, clause, phrase and finite verb. This section will focus on sentence, clause and phrase in the four selected texts, with the caveat that sentence is too rich and basic a concept to be captured in any verbal definition. It can be explicated, strictly speaking, only in terms of the entire rule-system to which it belongs.

CCDP has for sentence in the "grammatical" sense:

A sequence of words capable of standing alone to make an assertion, ask a question or give a command, usually consisting of a subject and a predicate.

Here "capable of standing alone" captures the grammatical independence of sentences. Though explicit cross-references are not given in this entry, we have elsewhere in CCDP: "clause: a group of words consisting of a subject and predicate and including a finite verb, that does not necessarily constitute a sentence"; "phrase: a group of words forming a syntactic constituent of a sentence" (with 
cross-reference to clause); "phrase marker: a representation '... of the constituent structure of a sentence". Constituent, however, is defined simply as "3. component part, ingredient" without reference to its widespread use in linguistics. Finite verb, however, is satisfactorily defined as "any form of a verb inflected for grammatical features such as person, number and tense".

CSD, a text for schools, strikes a different note:

A sentence is a group of words which, when written down, begins with a capital letter and ends with a full stop.

This is, of course, one of the many current senses of sentence in common use. But on this view such fragments as

Four beers.

Under the table.

would count as sentences. It would be an unhappy point of departure for language study. It is remarkable that CCDP and CSD have the same Chief Editor, Patrick Hanks, though the editorial teams do not otherwise seem to overlap. Clause in CCDP is defined in traditional terms, phrase rather unhappily as a "group of words considered as a unit, especially a saying"; constituent by way of "the constituents of a unit are its parts". Noun-phrase, incidentally, a pivotal concept for linguistic analysis, is not given an entry either in CCDP nor COD.

CSD's introductory mini-grammar uses sentence, clause and phrase without formally defining them, though it states that "the typical structure of an English clause is subject, verb, object". This side-steps clauses like "Mary slept" or like "James is a moron" and creates a conception of sentence which is exceedingly difficult to unteach, even at university level.

EUD, also a text for schools, has no entry at all for sentence (surprisingly in a book of over 1000 pages and about 13500 entries). For clause it has "a section of a sentence with its own finite verb"; phrase is pleasingly defined as "a group of words without a finite verb, usually forming part of a sentence; a short suitable expression". Both EUD and CSD leave the pivotal concept of finite verb to the teacher.

COD presents a more traditional picture of sentence than CCDP:

a

b

A set of words complete in itself as the expression of a thought, containing or implying a subject and predicate, and conveying a statement, question, exclamation or command.

A piece of writing or speech between two full stops or equivalent pauses, often including several grammatical sentences (e.g. 1 went, he came). 
Here a gives a "grammatical" sense, b one in common use, parallel to that given in CSD. Sense a roughly parallels CSD; the unverifiable "complete in itself as the expression of a thought" derives ultimately from the Techne Grammatike (c. 100 B.C.) of Dionysius Thrax (Robins 1979: 33).

The association of sentence with the options of statement, question, exclamation or command goes back to Protagoras in the fifth century B.C. (Robins 1979: 26). For clause COD has "a distinct part of a sentence, including a subject and predicate", thereby missing, as CSD does not, the simple sentence consisting of a single clause. Phrase is unhappily defined as "a group of words forming a conceptual unit but not a sentence": here structural would be more helpful than "conceptual". CCDP's "syntactic constituent" reflects the status of phrases as members of the linguistic system more happily. COD has no entry for phrase-marker.

The missing concept in all these definitions is that of "structure-dependence" (Chomsky 1957 and 1965: passim). The traditional metalanguage remains useful after two thousand years and has, much of it, been taken up into 20th-century linguistics, but there is little in the definitions cited to capture the concept of language as a manifestation of rule-governed behaviour.

\section{Structural Descriptions}

The structure-dependence of language creates the need for "structural descriptions" (Chomsky 1965) in which the disciplines of syntactician and lexicographer should converge. A major challenge to the lexicographer is that of creating "structural descriptions" that adequately reflect the valency, or patterning potential, of words or classes of words. This involves the choice of category labels as well as more extended description and exemplification. This section will sample a very few such descriptions, with particular reference to what Austin (1962) might have called "misfires".

In a book the size of a desk dictionary, some structural descriptions will be done well, others less well. Both COD and CCDP have full and felicitous entries for be; both, predictably, describe copula as well as locative-existential patterns with be, though only CCDP uses the term copula.

COD has a long and insightful entry for the, as has CCDP, both correctly identifying one of its functions as that of a marker of "given" information. Both distinguish the and $a$ as "definite" versus "indefinite" articles but COD marks both as adj. where CCDP calls both determiner, backing this with a useful note on the class of determiners in its Preliminaries. The label adj. assigns the to the same word-class as fat and beautiful (contrast Kaspaas is fat with 'Kaspaas is the) thus missing the useful generalization achieved by determiner. CSD also labels the "determiner", and explains determiner in its Preliminaries as "a word that introduces a noun phrase". 
EUD has "definite article" for the, but its explanation "used before a noun or adjective to show that that particular one is meant" hardly captures the complex lexicogrammar of the. CSD, in relating the to the far-reaching concept of "noun phrase", is moving in the direction of effective structural description.

Very, as in "a very bad cough", appears in COD as adv. It can be called an adverb only on Jespersen's view that "adverb" functions as a catch-all word-class for words that appear to fit no other. CCDP correctly identifies this very as an intensifier "used to add emphasis to adjectives that can be graded" and has a useful note in its Preliminaries on the intensifier class. (Regrettably it also marks very as adv., presumably to conciliate conservative readers.)

A challenging area for structural description is that of complementation, as in
(a) he declared that he was innocent,
(b) his intention to murder Desdemona, and
(c) capable of defeating the Kurds.

These examples are chosen to show that complements may be taken by certain classes of nouns and adjectives as well as by certain classes of verb (Quirk and Greenbaum 1972: 354 seq.).

COD indicates typical patterns of complementation by marking verbs "(foll. by to + infin.)" as in wants to learn or "(foll. by that + clause)" as in said that it was late. This practice is noted in the Preliminaries. CCDP has a very similar marking system not introduced in the Preliminaries. Thus the typical complements of declare "(3. tr. usu. foll. by that + clause)" and intention "(often foll. by to + infin., or of + verbal noun)" are sketched in COD and, less fully, in CCDP. For capable COD and CCDP have only "(foll. by of)", without specifying the pattern with gerund reflected in of defeating the Kurds,

The school dictionaries attempt less. CSD has illustrations for declare, but not with a that-clause as complement. For intention it does show an infinitival complement and for capable a complement with gerund (capable of causing death). EUD has no entry for declare; illustrates intend/intention with an enterprising range of patterns, but shows capable ("a capable housewife") only in attributive position. Explain is illustrated only with "please explain your absence". The equally common pattern with that + clause ("explained that he couldn't do it") is not illustrated either in EUD or CSD. Complementation is clearly an area on which lexicographers and syntacticians could usefully pool resources.

\section{Conclusions}

Despite the exploratory status of this article, a few conclusions emerge: 
(1)

The prevailing divorce between dictionaries and grammars is damaging to both. Editors and publishers of dictionaries should consider including short grammatical outlines in future texts, planning these to reconcile the immediate needs of users with the state of the art in language description.

(2) The traditional metalanguage of commercial dictionaries is beginning, in some publishing houses, to be supplemented by a few of the more viable terms of contemporary linguistics.

Basic linguistic terminology, compared with that of other disciplines, is under-represented in dictionaries of English as L1.

School dictionaries and usage handbooks need critical scrutiny by competent judges. EUD for example, is built on the brilliant concept of detailed exemplification with an absolute minimum of explanatory text, but fails at a number of points because structures of very high frequency are not exemplified.

A major stumbling block is created by the failure of universities and training colleges to provide future teachers with an effective briefing on language. Without this, the present shortage of competent authors and evaluators of dictionaries for use in schools is likely to continue.

\section{References}

Allen, R.E. (Ed.). 1990. Concise Oxford Dictionary. Oxford: Clarendon Press.

Alswang J. and A. van Rensburg (Eds.). 1988. English Usage Dictionary for Southern African Schools. Third edition. Johannesburg: Educum.

Austin, J. 1962. How to do Things with Words. Oxford: Oxford University Press.

Bloomfield, L. 1933. Language. New York: Harper and Row.

Chomsky, N. 1957. Syntactic Structures. The Hague: Mouton.

Chomsky, N. 1965. Aspects of the Theory of Syntax. Cambridge, Mass: MIT Press.

Halliday, M. 1978. Language as Social Semiotic. London: Edward Amold.

Hanks, Patrick (Chief Ed.). 1989. Collins Concise Dictionary Plus. Glasgow: Collins.

Hanks, Patrick (Chief Ed.). 1989. Collins School Dictionary. Glasgow: Collins.

Hudson, R. 1984. Word Grammar. Oxford: Basil Blackwell.

Johnson, S. 1755. A Dictionary of the English Language. Reprint of 1840. London: Ball, Amold and Co.

Procter, Paul (Chief Ed.). 1978. Longman Dictionary of Contemporary English. Harlow and London: Longman.

Quirk, R. and S. Greenbaum. 1972. A University Grammar of English. London: Longman.

Robins, R.H. 1979. A Short History of Linguistics. London and New York: Longman. 